\title{
Effects of Ion Doping on the Optical Properties of Dye-Sensitized Solar Cells
}

\author{
Di Gu1 ${ }^{*}$, Yanji Zhu1, Zhigang $\mathrm{Xu}^{2}$, Nan Wang2, Chuang Zhang \\ ${ }^{1}$ College of Chemistry and Chemical Engineering, Northeast Petroleum University, Qaqing, China \\ ${ }^{2}$ Daqing Oilfield Engineering Co. Ltd., Qaqing, China \\ Email: 48184820@qq.com
}

Received 8 August 2014; revised 23 September 2014; accepted 8 October 2014

Copyright (C) 2014 by authors and Scientific Research Publishing Inc.

This work is licensed under the Creative Commons Attribution International License (CC BY).

http://creativecommons.org/licenses/by/4.0/

cc) (i) Open Access

\begin{abstract}
Dye-sensitized solar cells (DSC) play a leading role in the third generation photovoltaics due to their low cost, easy fabrication process, high conversion efficiency and good stability. As a media of dye adsorption, electron transport, and electrolyte diffusion, the nanocrystalline semiconductor photoanode plays a key role during light-to-electricity conversion in DSC. This paper studies the influence of different ions doping and different concentration of ion doping on the electrical and optical properties of DSC, through the photoelectric property test of DSC. We learn that $\mathrm{Zn}^{2+}$ doped $\mathrm{TiO}_{2}$ photoanode is the best. At the same time there was an optimum doping concentration which was $\mathbf{0 . 0 5 \%}$ (mole fraction).
\end{abstract}

\section{Keywords}

\section{Anode, Doping, Concentration of Ion Doping, Photoelectric Property}

\section{Introduction}

Due to the low price, easy fabrication process, high conversion efficiency and good stability, since the DSC in 1991, [1] has made breakthrough progress, and has aroused widespread concern in the academic circles and the business community [2]-[6]. In recent years, doping $\mathrm{TiO}_{2}$ with metal and nonmental elements has been considered as a promising way to tailor the electronic properties of $\mathrm{TiO}_{2}$ photoanode in $\mathrm{DSC}$ and has succeeded in improving photovoltaic performance of DSC [7]-[11]. Performance of doped metal ions on monocrystalline or polycrystalline $\mathrm{TiO}_{2}$ present in the crystal lattice has become good electron trap. It can reduce electron-hole pair recombination, extend the life of charge, thus to improve the efficiency of DSC [12]. This paper studied the influence of different ion doping and different concentration of ion doping on the electrical and optical properties

${ }^{*}$ Corresponding author.

How to cite this paper: Gu, D., Zhu, Y.J., Xu, Z.G., Wang, N. and Zhang, C. (2014) Effects of Ion Doping on the Optical Properties of Dye-Sensitized Solar Cells. Advances in Materials Physics and Chemistry, 4, 187-193.

http://dx.doi.org/10.4236/ampc.2014.410022 
of DSC, and confirmed the best concentration and the best types of ion doping through optical performance testing.

\section{Experimental}

\subsection{The Film Preparation Method}

The sol-gel method for preparing anode $\mathrm{TiO}_{2}$ films, sol-gel method is a common method for preparing wet chemical materials [1] [13]-[16]. Sol-gel derived samples high uniformity, high purity of products, easy control of the reaction process, has great advantages in the application of the film, becoming one of the most commonly used method for preparing thin films. $\mathrm{TiO}_{2}$ film composition prepared using different process methods or parameters, structure, orientation and thickness are the differences.

\subsection{Preparation of $\mathrm{TiO}_{2}$ Sol-Gel}

Tetrabutyl titanate hydrolysis reaction in an acidic solution [17]:

$$
\begin{gathered}
\mathrm{Ti}(\mathrm{OR})_{4}+\mathrm{H}_{2} \mathrm{O}-\mathrm{Ti}(\mathrm{OR})_{3}(\mathrm{OH})+\mathrm{ROH} \\
\mathrm{Ti}(\mathrm{OR})_{4}+4 \mathrm{H}_{2} \mathrm{O}--\mathrm{Ti}(\mathrm{OR})_{4}+4 \mathrm{ROH} \\
\mathrm{Ti}(\mathrm{OR})_{4}+\mathrm{Ti}(\mathrm{OR})_{3}(\mathrm{OH})-\mathrm{Ti}(\mathrm{OR})_{3} \mathrm{O}(\mathrm{RO})_{3} \mathrm{Ti}+\mathrm{ROH} \\
\mathrm{Ti}(\mathrm{OR})_{3}(\mathrm{OH})+\mathrm{Ti}(\mathrm{OR})_{3}(\mathrm{OH})--\mathrm{Ti}(\mathrm{OR})_{3} \mathrm{O}(\mathrm{RO})_{3} \mathrm{Ti}+\mathrm{H}_{2} \mathrm{O}
\end{gathered}
$$

The hydrolyzed reaction mainly (1) and (2) out of the way, the product was incomplete hydrolyzate $\mathrm{Ti}(\mathrm{OR})_{3}(\mathrm{OH})$ and $\mathrm{Ti}(\mathrm{OH})_{4}, \mathrm{Ti}(\mathrm{OH})_{4}$ lose a water molecules generated $\mathrm{TiO}_{2}$ colloidal particles. Polycondensation reaction (3) and (4) happened after 10 hours, polycondensation product gel form titanium oxide.

Chemically pure tetrabutyl titanate as raw material in this experiment, using ethanol as solvent, diethanolamine as complexing agent, nitric acid as catalyst. Experiment steps were as follows:

1) Prepare a mixture A with tetrabutyl titanate, ethanol and diethanolamine, fully stirred to give a homogeneous mixture.

2) Prepare a uniformly mixed mixture A with ethanol, deionized water and nitric acid.

3) Under magnetic stirring, the above mixture B was added into the mixture A dropwise to obtain a uniform, light yellow transparent sol, and the hydrolysis polycondensation reaction at room temperature to obtain sol C.

The mole ratio of tetrabutyl titanate, ethanol, diethanolamine and and nitric acid was 12:48:4:1:0.6.

\subsection{Ion Doping}

The desired ionic salt was put into B solution. Adding the solution B in solution A dropwise under magnetic stirring to give a homogeneous, light yellow transparent sol. The hydrolysis polycondensation reaction at room temperature to obtain solution $\mathrm{C}$.

\subsection{Cell Production}

The $\mathrm{TiO}_{2}$ film was prepared by sol-gel method, drying at room temperature and then placing the crucible in a muffle furnace at $20^{\circ} \mathrm{C} / \mathrm{min}$ at $500^{\circ} \mathrm{C}$ heated to a constant temperature for two hours, then cooled in the furnace. After hydrolysis of the intermediate product suitable high-temperature annealing was completely decomposed, residual organic matter can be completely removed, and finally completely dehydrated, only closely integrated with the substrate of titanium dioxide films.

Using DMF solution with Eosin Y as sensitizer, the concentration of $0.001 \mathrm{~g} / \mathrm{mL}$. Putting the annealed $\mathrm{TiO}_{2}$ film into the dye solution and rushing floated color with ethanol after 24 hours to make the anode. Using acetonitrile solution with $\mathrm{KI}$ and $\mathrm{I}_{2}$ as electrolyte. The counter electrode was prepared by electroplating method on FTO conductive glass with pt.

The prepared $\mathrm{TiO}_{2}$ film colored face up on the table, the pore size of $0.5 \mathrm{~cm}^{2}$ of silicone sheet on the anode and the counter electrode on top, with a clip to clip up on both sides of the battery, electrolyte injected with a syringe. Cell production is complete to measure optical properties. 


\section{Results and Discussion}

\subsection{Effect of Different Ion-Doped Optical Performance of DSC}

Testing the DSC with Beijing changtuo company CHF-XM-500W xenon lamp as the light source, the incident light intensity was $73.1 \mathrm{~mW} / \mathrm{cm}^{2}$, the open circuit voltage of $V_{o c}$ and short circuit current density $I_{s c}$. The open circuit voltage can be seen from Figure 1, $\mathrm{Nd}^{3+}$ doped $\mathrm{TiO}_{2}$ thin films was lower, $\mathrm{Zn}^{2+}$ doped $\mathrm{TiO}_{2}$ thin film photovoltaic best performance, cell power was highest, indicating that the effect of doping of $\mathrm{Zn}^{2+}$ was the best in these three kinds of ions.

As can be seen from the Figure 1, not only the curve hardness of ion-doped $\mathrm{TiO}_{2}$ film was significantly better than undoped $\mathrm{TiO}_{2}$ film, but also the current and voltage was higher than the undoped film. It illustrated the truth of certain mount of doping ions can improve the property of $\mathrm{TiO}_{2}$ thin films. This was because the oxide melting point have a certain influence on the phase transformation of $\mathrm{TiO}_{2}$, when the oxide melting point was higher than $\mathrm{TiO}_{2}$, can inhibit the transformation of anatase to rutile, and when the oxide melting point lower than $\mathrm{TiO}_{2}$, can promote the transformation, and the lower the melting point effect more obvious.

Using the RIGAKU D/MAX-2200 type PC X-ray diffraction of the phase of the sample were measured for the $\mathrm{Cu}$ target radiation. $\lambda=0.15418 \mathrm{~nm}$, the working voltage of $40 \mathrm{kV}$, current of $30 \mathrm{~mA}$, the scanning range of $10^{\circ}-80^{\circ}$, the scanning speed was $20 / \mathrm{min}$. As can be seen from the Figure 2 , doping ions easily lead redox reaction in the titania lattice surface, then produced oxygen vacancy or interstitial titanium by diffusion, thereby inhibiting the interaction between different titanium atoms, transition hinder anatase to rutile phase, to improve the light absorption ability of $\mathrm{TiO}_{2}$ thin films.

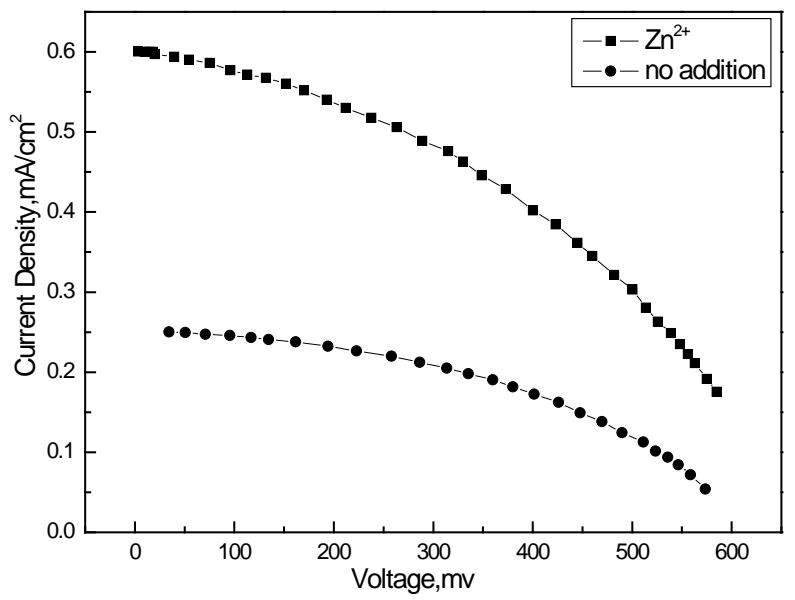

(a)

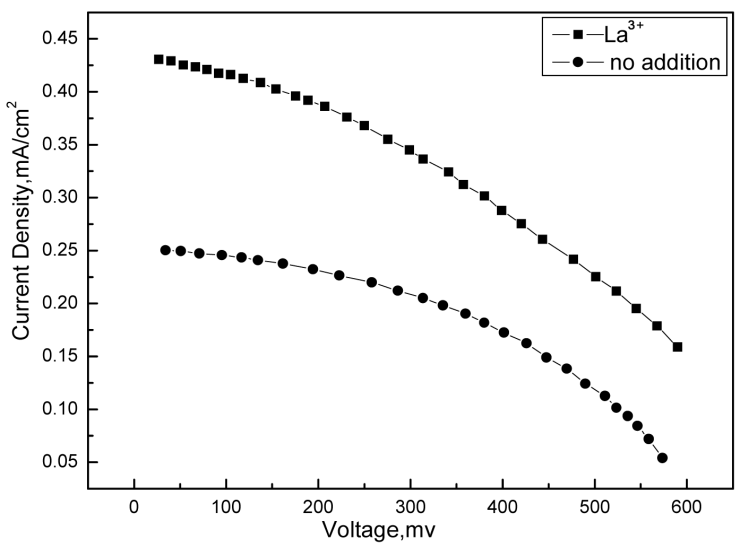

(b)

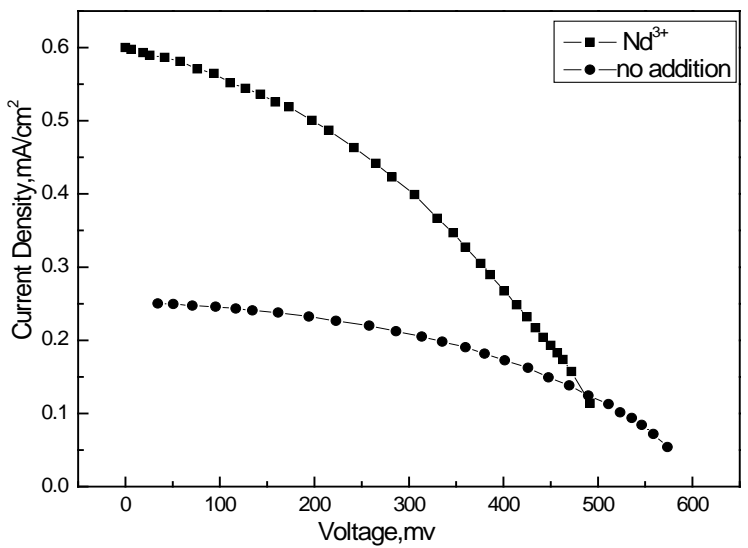

(c)

Figure 1. The I - V curve of ion doped DSC. (a) The I - V curve of $\mathrm{Zn}^{2+}$ doped DSC; (b) The I - V curve of La ${ }^{3+}$ doped DSC; (c) The I - V curve of $\mathrm{Nd}^{3+}$ doped DSC. 


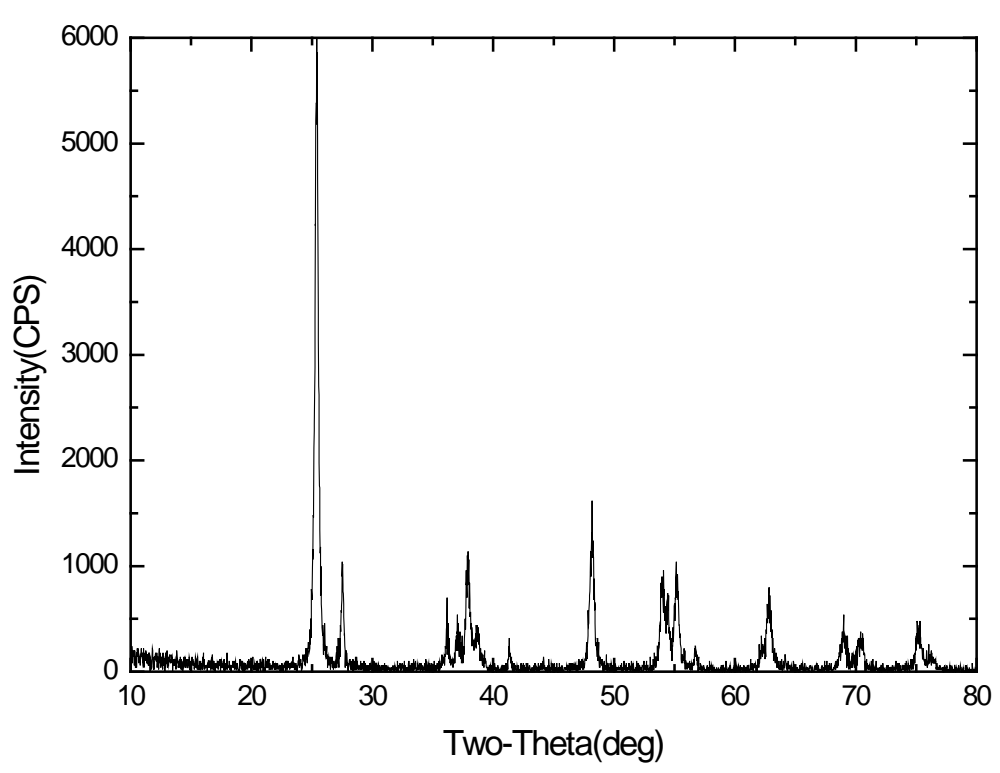

Figure 2. XRD patterns of Titania films.

\subsection{UV-Vis Characterization of Different ion Doped $\mathrm{TiO}_{2}$ Thin Film}

The characteristics of samples were examined through a UV-Vis spectrophotometer type UV-2550 produced by Japanese Shimadzu Company, scan speed was medium, the slit width was $2 \mathrm{~nm}$, wavelength range was $200 \mathrm{~nm}$ to $800 \mathrm{~nm}$.

Figure 3 was the UV-Vis spectra of $\mathrm{TiO}_{2}$ films doped with ions in the $300-600 \mathrm{~nm}$. It can be seen from that the spectra in the wavelength range of $500 \mathrm{~nm}$ or more, whether the $\mathrm{TiO}_{2}$ film was doped with ions or not, light absorption was relatively small. Absorb light beginning between $300-400 \mathrm{~nm}$, and the wavelength was shifted to shorter wavelength direction as the absorption peak was more obvious. While in the UV range, $\mathrm{TiO}_{2}$ films have a strong absorption of light.

The spectral curve changed on the form compared with the non-doped $\mathrm{TiO}_{2}$ films. The absorption peak shifted to longer wavelengths, spectral red shift. Expand the scope of $\mathrm{TiO}_{2}$ nanoparticles in response to visible light direction, improved the absorption properties in a certain extent. The band gap of $\mathrm{TiO}_{2}$ thin film doped with $\mathrm{Zn}^{2+}$ is $2.77 \mathrm{eV}$, the band gap of $\mathrm{TiO}_{2}$ thin film doped with $\mathrm{La}^{3+}$ is $2.51 \mathrm{eV}$, the band gap of $\mathrm{TiO}_{2}$ thin film doped with $\mathrm{Nd}^{3+}$ is $2.71 \mathrm{eV}$, all smaller than the band gap of undoped $\mathrm{TiO}_{2}$ films $(3.0 \mathrm{eV})$, demonstrated that the doping ion can improve the photocatalytic activity of $\mathrm{TiO}_{2}$ thin films.

\subsection{Effects of Doping Concentration on the Photoelectric Properties of DSC}

Many studies have shown that ion doping with an optimal concentration. With increasing the concentration of the doping, the surface space charge layer is narrowed, electrons and holes are generated by light excitation $\mathrm{TiO}_{2}$ and can be effectively separated, the lifetime of photo-induced carriers prolonged, but when the doping concentration is lower than the optimal concentration, there is not enough traps in the semiconductor to capture the photo-induced carriers, electrons and holes can not reach the most effective separation; When the optimum doping concentration, the space charge layer thickness is exactly equal to the incident light penetration depth, the photo-generated electrons and holes have the optimal separation, the most favorable to the photocatalytic reaction; It would cause an increase of photo-induced carriers recombination in the surface when excess dopant to reduce the photocatalytic efficiency.

The doping of $\mathrm{Zn}^{2+}$ as an example to illustrate the effects of different doping concentration on the properties of DSC. The doping concentration in solution was respectively $0.001 \%, 0.03 \%, 0.05 \%, 0.1 \%, 0.2 \%$ (mole fraction). As can be seen from Figure 4, the open circuit voltage and short circuit current increased with the ions concentration increased. However, when reached a certain value, the open circuit voltage and short circuit current decreased, which also proved the existence of an optimum value of ions concentrationt, and the optimum value was $0.05 \%$. 


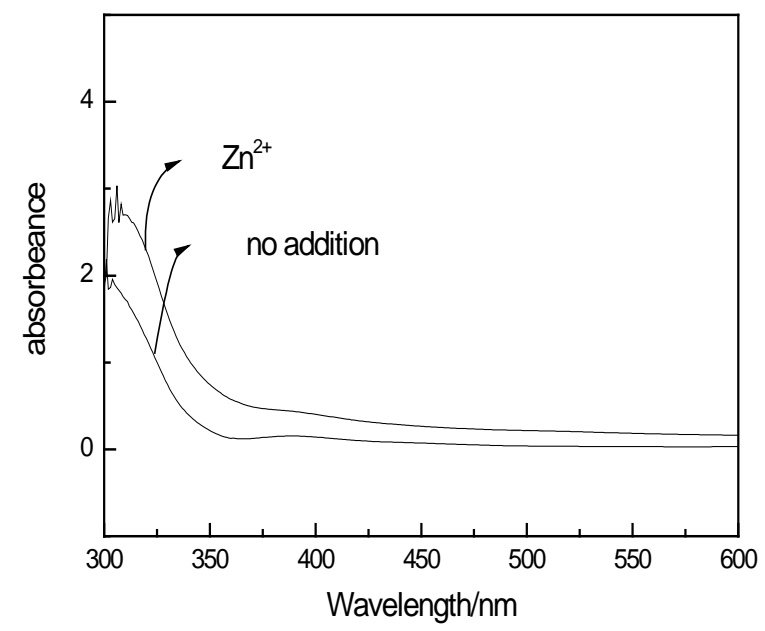

(a)

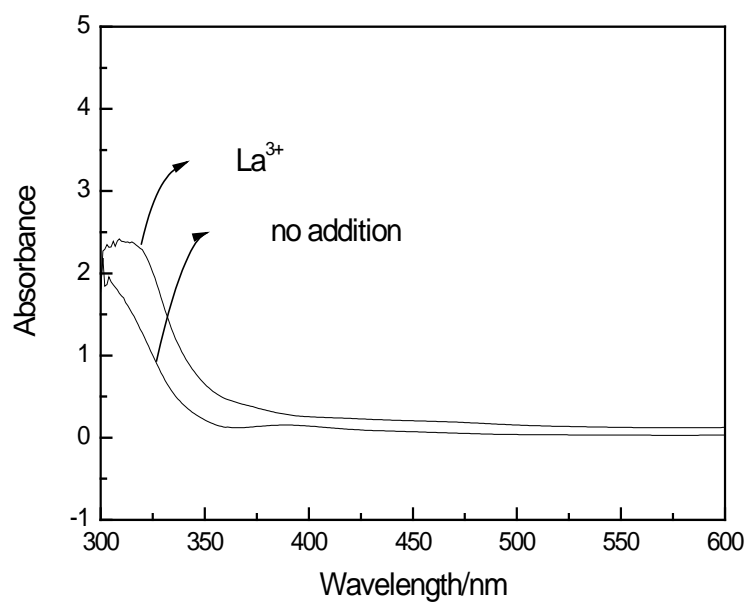

(b)

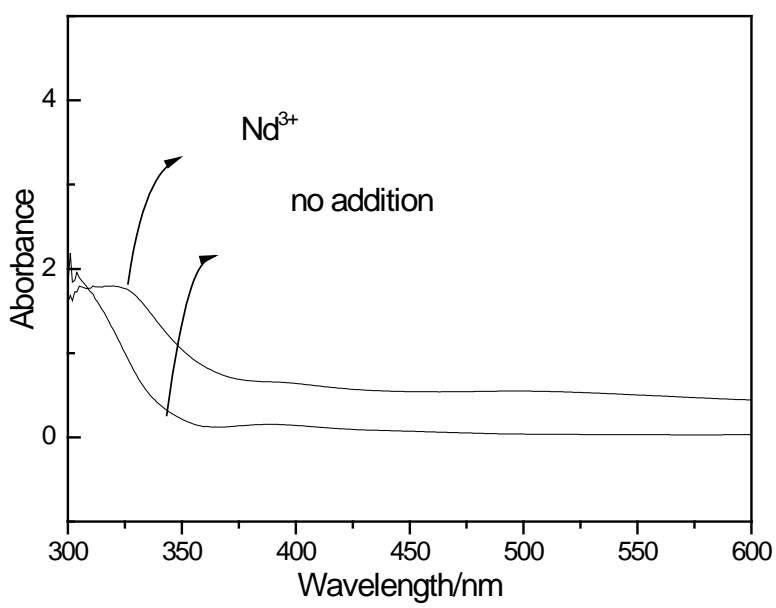

(c)

Figure 3. UV-Vis spectra curve of ions doped $\mathrm{TiO}_{2}$ thin films. (a) UV-Vis spectra curve of $\mathrm{Zn}^{2+}$ doped $\mathrm{TiO}_{2}$ thin film; (b) $\mathrm{UV}$-Vis spectra curve of $\mathrm{La}^{3+}$ doped $\mathrm{TiO}_{2}$ thin film; (c) UV-Vis spectra curve of $\mathrm{Nd}^{3+}$ doped $\mathrm{TiO}_{2}$ thin film.

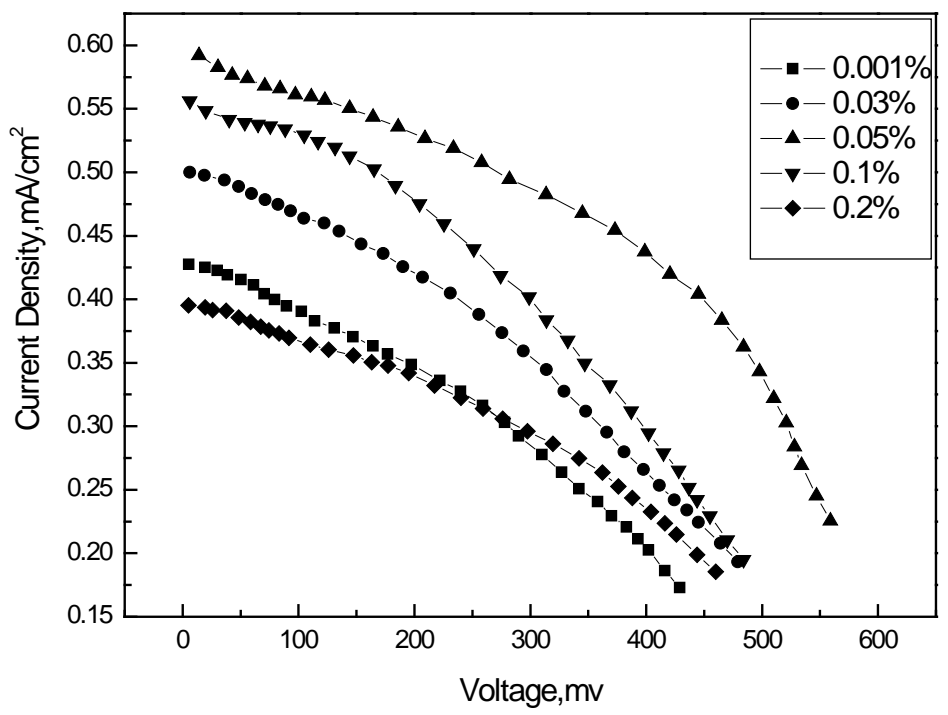

Figure 4. The I-V curve of different concentrations ions doped DSC. 
Semiconductor $\mathrm{ZnO}$ and $\mathrm{TiO}_{2}$ belong to different band gap, in both the interface the $\mathrm{Ti}^{4+}$ into the $\mathrm{ZnO}$ lattice instead of $\mathrm{Zn}^{2+}$ causing a charge imbalance due to $\mathrm{Zn}^{2+}$ ionradius is larger than the radius $\mathrm{Ti}^{4+}$, in order to balance the charge, more - $\mathrm{OH}$ was absorbed to the surface, and the surface adhesion of the $-\mathrm{OH}$ to accept the photogenerated holes. This reduces the probability of the photogenerated hole and electron recombination, improves the separation of photogenerated electrons and holes, which exhibits better photocatalytic activity. However, when doped $\mathrm{Zn}^{2+}$ too much, $\mathrm{ZnO}$ and $\mathrm{TiO}_{2}$ solid solution has reached saturation, the excess of $\mathrm{Zn}^{2+}$ in the form of $\mathrm{ZnO}$ deposited on the surface of $\mathrm{TiO}_{2}$ grains, reducing the effective Specific surface area of $\mathrm{TiO}_{2}$ films. And because the band gap of $\mathrm{ZnO}$ is greater than $\mathrm{TiO}_{2}$, the UV-visible irradiation does not cause photocatalytic reaction, so the accumulation of $\mathrm{ZnO}$ on the surface of $\mathrm{TiO}_{2}$ hinder the photocatalytic reaction, causing lower photocatalytic activity of $\mathrm{TiO}_{2}$ films.

The $\mathrm{Zn}^{2+}$ optimum doping amount is $0.05 \%$, because then the transfer rate of carriers of the fastest, the separation of electron hole pair efficiency is the highest, the photocatalytic activity is the strongest. When $\mathrm{Zn}^{2+}$ doping amount is less than $0.05 \%$, the defect levels and impurity levels is separating center of electron-hole pairs; When $\mathrm{Zn}^{2+}$ doping greater than $0.5 \%$, the defect levels and impurity levels is recombination center of electron-hole pairs. carrier recombination rate accelerated, electron-hole pairs separation efficiency decreases.

\subsection{UV-Vis Spectra of Different Concentration Ion Doped $\mathrm{TiO}_{2}$ Thin Film}

Figure 5 was the UV-Vis spectra of $\mathrm{TiO}_{2}$ films doped with $\mathrm{Zn}^{2+}$ between $300 \mathrm{~nm}$ and $600 \mathrm{~nm}$, including 1, 2, 3, 4, 5 respectively represent the doping concentrations were $0.001 \%, 0.03 \%, 0.05 \%, 0.1 \%, 0.2 \%$ (mole fraction). As we can be seen from the spectra, the shape of the curve changed with increasing the concentration, the absorption peak shifted to longer wavelengths. However, when the concentration continues to increase, the absorption peak moves to shorter wavelength. It also showed the presence of an optimum doping concentration, and the most preferably concentration of $0.05 \%$ (mole fraction). This was consistent with previous analyzes. It presented the first band gap decreased after the increase. It also showed that there was an optimal doping concentration. The band gap of the mixture narrowed compared with pure $\mathrm{TiO}_{2}$, the right concentration of $\mathrm{Zn}^{2+}$ doped $\mathrm{TiO}_{2}$ improved ability to absorb long-wave photons.

\section{Conclusion}

This paper studied the regulation of photoelectric properties though ions doped in anode of DSC. $\mathrm{Zn}^{2+}, \mathrm{La}^{3+}$ and $\mathrm{Nd}^{3+}$ of three kinds of ion doping were tested on the photoelectric properties of $\mathrm{TiO}_{2}$ films, and the results showed that $\mathrm{Zn}^{2+}$ doped $\mathrm{TiO}_{2}$ photoanode was the best. At the same time there was an optimum doping concentration which was $0.05 \%$ (mole fraction). The UV-Vis spectra of doped $\mathrm{TiO}_{2}$ also confirmed this conclusion.

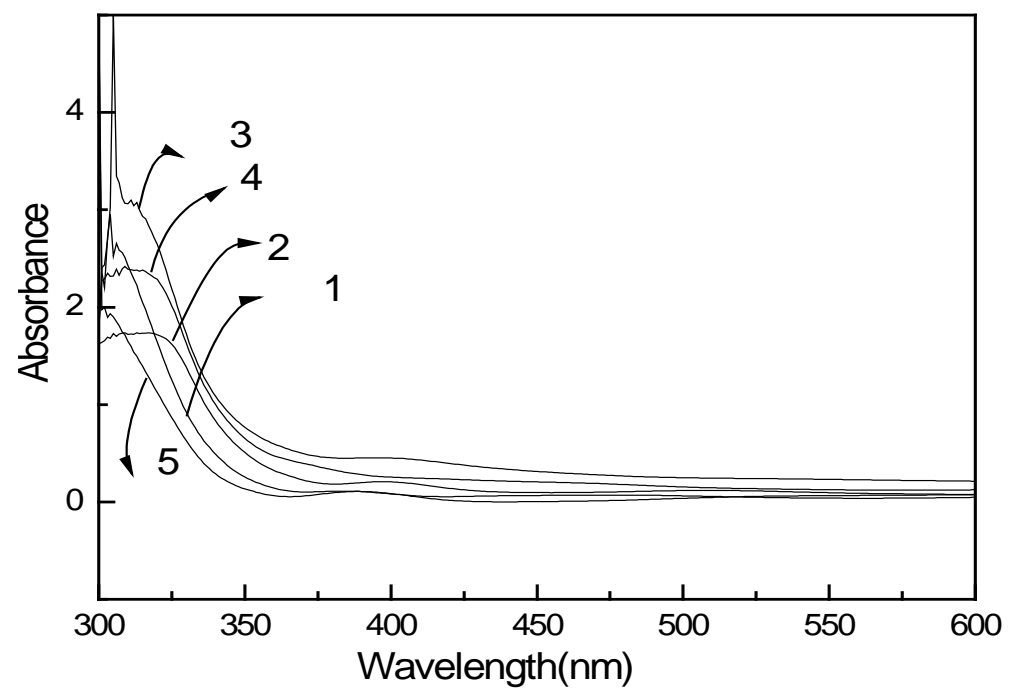

Figure 5. UV-Vis spectra of different concentrations of ions doped $\mathrm{TiO}_{2}$ thin films. 
Future research should focus on the doping mechanism, through in-depth study of the mechanism, to avoid adverse effects on the DSC doping elements brought to more effectively improve the photoelectric conversion efficiency of DSC.

\section{References}

[1] O’Regn, B. and Gratzel, M. (1991) A Low-Cost High Efficiency Solar Cell Based on Dye-Sensitized Colloidal TiO 2 Films. Nature, 353, 737-740. http://dx.doi.org/10.1038/353737a0

[2] Gratzel, M. (2005) Solar Energy Conversion by Dye-Sensitized Photo-Voltaic Cells. Inorganic Chemistry, 44, 68416851. http://dx.doi.org/10.1021/ic0508371

[3] Gra1tze, M. (2004) Conversion of Sunlight to Electric Power by Nanocrystalline Dye-Sensitized Solar Cells. Journal of Photochemistry and Photobiology A: Chemistry, 164, 3-14. http://dx.doi.org/10.1016/j.jphotochem.2004.02.023

[4] Gratzel, M. (2003) Dye-Sensitized Solar Cells. Journal of Photochemistry and Photobiology C: Photochemistry Reviews, 4, 145-153. http://dx.doi.org/10.1016/S1389-5567(03)00026-1

[5] Burschka, J., Pellet, N., Moon, S.-J., et al. (2013) Sequential Deposition as a Route to High-Performance PerovskiteSensitized Solar Cells. Nature, 499, 316-319. http://dx.doi.org/10.1038/nature12340

[6] Van De Lagemaat, J. and Frank, A.J. (2001) Nonthermalized Electron Transport in Dye-Sensitized Nanocrystalline $\mathrm{TiO}_{2}$ Films; Transient Photocurrent and Random Walk Modeling Studies. The Journal of Physical Chemistry B, 105, 11194-11205. http://dx.doi.org/10.1021/jp0118468

[7] Asxhi, R., Morikxwx, T., Ohwxki, T., et al. (2001) Visible-Light Photocatalysis Innitrogen Doped Titanium Oxides. Science, 293, 269-271. http://dx.doi.org/10.1126/science.1061051

[8] Konstantinova, E.A., Kokorin, A.I., Lips, K., Sakthivel, S. and Kisch, H. (2009) EPR Study of the Illumination Effect on Properties of Paramagnetic Centers in Nitrogen-Doped $\mathrm{TiO}_{2}$ Active in Visible Light Photocatalysis. Applied Magnetic Resonance, 35, 421-427. http://dx.doi.org/10.1007/s00723-009-0173-5

[9] Menzies, D.B. and Dai, Q. (2007) Modifcation of Mesoporous $\mathrm{TiO}_{2}$ Electrodes by Surface Treatment with Titanium (IV), Indium (III) and Zirconium (IV) Oxideprecursors: Preparation, Characterization and Photovoltaic Performance in Dye-Sensitized Nanocrystalline Solar Cells. Nanotechnology, 18, 125608-125618. http://dx.doi.org/10.1088/0957-4484/18/12/125608

[10] Zhang, C.N. and Dai, S. (2011) Charge Recombination and Band-Edge Shift in the Dye-Sensitized $\mathrm{Mg}^{2+}-\mathrm{Doped} \mathrm{TiO}_{2}$ Solar Cells. The Journal of Physical Chemistry C, 115, 16418-16424. http://dx.doi.org/10.1021/jp2024318

[11] Tian, H.J., Hu, L.H., Zhang, C.N., Liu, W.Q., Huang, Y., Mo, L., Guo, L., Sheng, J. and Dai, S.Y. (2010) Retarded Charge Recombination in Dye-Sensitized Nitrogen-Doped $\mathrm{TiO}_{2}$ Solar Cells. Journal of Physical Chemistry C, 114, 1627-1632. http://dx.doi.org/10.1021/jp9103646

[12] Du1rr, M., Rosselli, S., Yasuda, A. and Nelles, G. (2006) Band-Gap Engineering of Metal Oxides for Dye-Sensitized Solar Cells. Journal of Physical Chemistry B, 110, 21899-21902. http://dx.doi.org/10.1021/jp063857c

[13] Ito, S., Murakami, T.N., Comte, P., Liska, P., Grätzel, C., Nazeeruddin, M.K. and Grätzel, M. (2008) Fabrication of Thin Film Dye Sensitized Solar Cells with Solar to Electric Power Conversion Efficiency over 10\%. Thin Solid Films, 516, 4613-4619. http://dx.doi.org/10.1016/j.tsf.2007.05.090

[14] Alias, S.S. and Mohamad, A.A. (2014) Synthesis of Zinc Oxide by Sol-Gel Method for Photoelectrochemical Cells. Springer Briefs in Materials, Springer, Berlin.

[15] Innocenzi, P., Zub, Y.L. and Kessler, V.G. (2008) Sol-Gel Methods for Materials Processing. NATO Science for Peace and Security Series C: Environmental Security.

[16] Hočevar, M., Krašovec, U.O., Berginc, M., Dražič, G., Hauptman, N. and Topič, M. (2008) Development of TiO ${ }_{2}$ Pastes Modified with Pechini Sol-Gel Method for High Efficiency Dye-Sensitized Solar Cell. Journal of Sol-Gel Science and Technology, 48, 156-162.

[17] Pandey, R.N., Chandra Babu, K.S. and Srivastava, O.N. (1996) High Conversion Efficiency Photoelectrochemical Solar Cells. Progress in Surface Science, 52, 125-192. http://dx.doi.org/10.1016/0079-6816(96)00009-3 
Scientific Research Publishing (SCIRP) is one of the largest Open Access journal publishers. It is currently publishing more than 200 open access, online, peer-reviewed journals covering a wide range of academic disciplines. SCIRP serves the worldwide academic communities and contributes to the progress and application of science with its publication.

Other selected journals from SCIRP are listed as below. Submit your manuscript to us via either submit@scirp.org or Online Submission Portal.
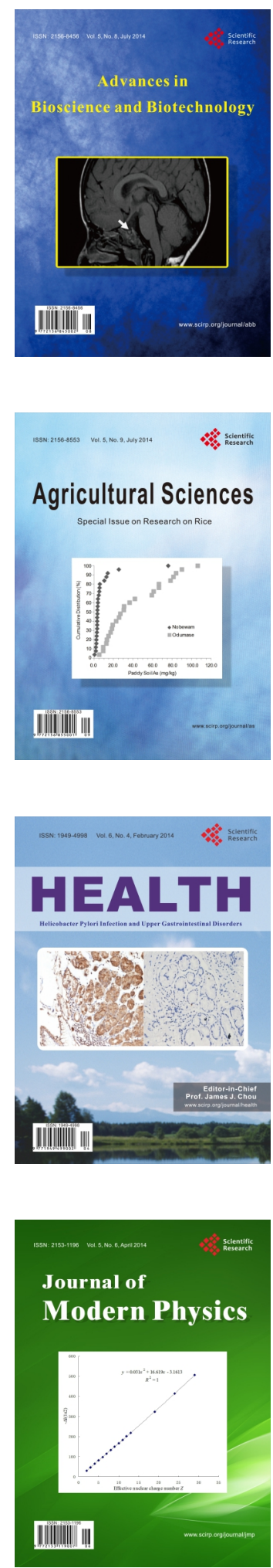
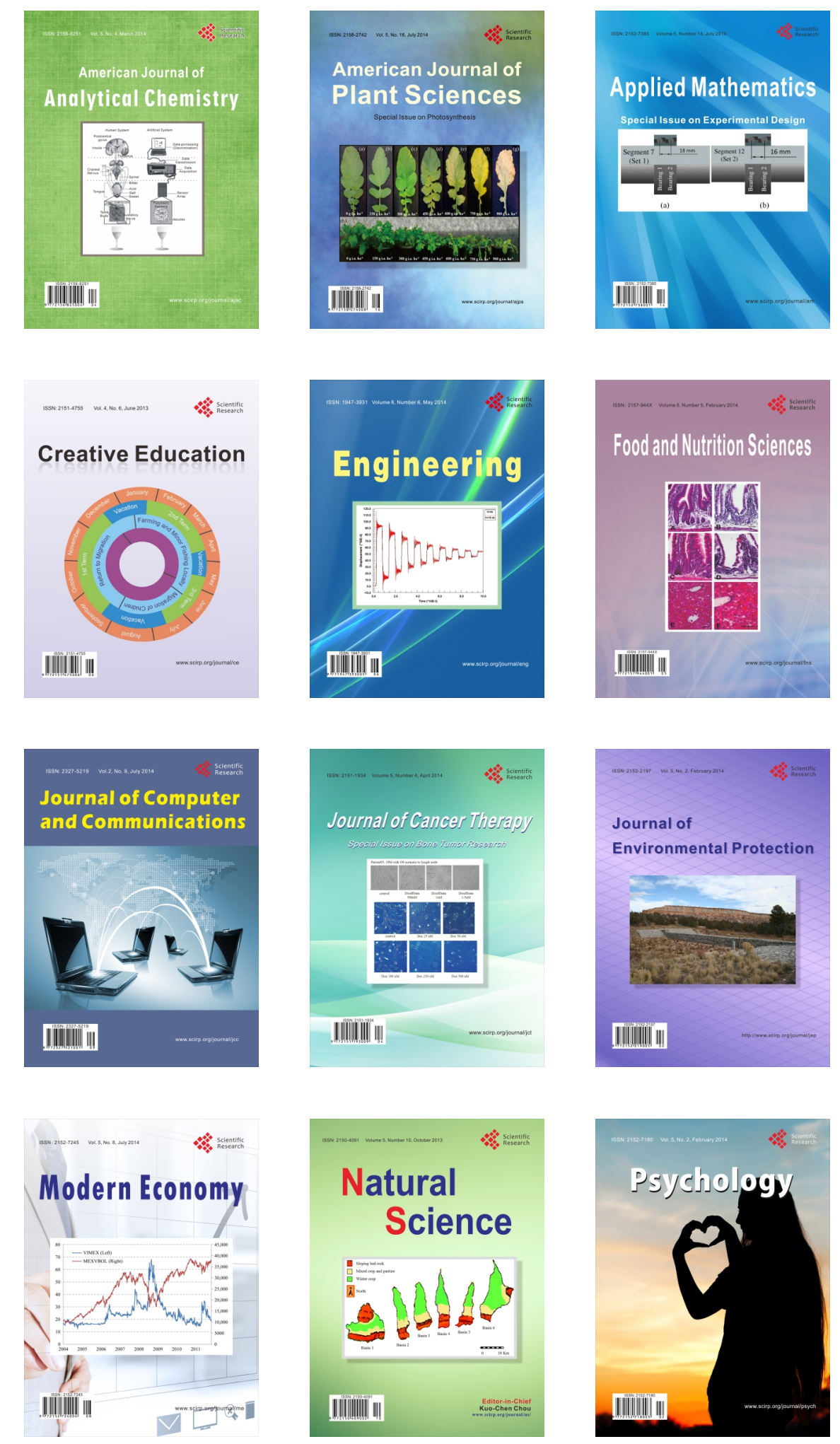